\title{
児童から大学生にいたる若年者層の ファーストフードの利用実態調査
}

\author{
浅 野 真智子*1, 深 蔵 紀 子*2, 尾 立 純 子*3, 瓦 家 千代子*4, \\ 難 波 敦 子*5, 安 田 直 子*6, 山本 悦 子*7 \\ ${ }^{* 1}$ 大阪国際女子大学, ${ }^{* 2}$ 大阪国際女子短期大学, ${ }^{* 3}$ 大阪市立環境科学研究所付設栄養専門学校, \\ ${ }^{* 4}$ 元大阪市立環境科学付設栄養専門学校, ${ }^{* 5}$ 常磐会短期大学, ${ }^{* 6}$ 金蘭短期大学, ${ }^{* 7}$ 大阪女子学園短期大学 \\ Use of Fast Foods among Young People \\ Machiko Asano*1, Noriko Fukakura*2, Junko Odachi*3, Chiyoko Kawaraya*4, \\ Atsuko Nanba ${ }^{* 5}$, Naoko Yasuda ${ }^{* 6}$ and Etsuko Yamamoto*7 \\ ${ }^{* 1}$ Osaka International Women's College $;{ }^{* 2}$ Osaka International Women's Junior College ; \\ ${ }^{*}$ College of Osaka City Institute of Public Health and Environment Sciences, \\ ${ }^{* 4}$ Formerly College of Osaka City Institute of Public Health and Environment Sciences ; \\ ${ }^{* 5}$ Tokiwakai Junior College ; ${ }^{* 6}$ Kinran Junior College ; ${ }^{* 7}$ Osaka Jyoshigakuen Junior College
}

A survey was conducted on the use of fast foods among young people from schoolchildren to university students and its effect on diet was evaluated.

Thirty-two percent of the subjects reported eating fast foods once or more per week (group A), while the other subjects reported twice or less per month (group B). Among the reasons quoted for the use of fast foods, "cheap price" and "good taste" accounted for about $40 \%$ and then "convenience". Schoolchildren quoted "cheap price" as the biggest reason and then "pleasure". The subjects tended to eat hamburger, French fries and fried chicken for lunch and snacks, doughnuts, hot dogs and takoyaki for snacks, pizza for dinner, and okonomiyaki, noodles and rice dishes for lunch and dinner. Hamburger, French fries and fried chicken tended to be eaten at a restaurant, pizza and okonomiyaki at home, doughnuts, hot dogs, noodles and rice dishes at a restaurant and at home, and takoyaki at home and at outdoor stands. Schoolchildren and junior high school children tended to eat fast foods with their family, while university students and high school students tended to eat fast foods, except for pizza and okonomiyaki, with their friends.

Almost all the subjects were satisfied with the taste of fast foods, although many complained about the quantity of fried chicken and about the price of pizza and fried chicken. Group A subjects more often skipped breakfast than group B subjects, and group B subjects more often ate breakfast and dinner with their family $(p<0.01)$. Some differences in health-related behavior were found between groups A and B, with group A subjects tending to have worse health conditions. The percentages of those who ate balanced meals consisting of a staple food, main dish and side dish for breakfast, lunch and dinner were $3.7 \%, 18.9 \%$ and $25.8 \%$, respectively. These percentages were higher for group B than for group A $(p<0.01)$. The percentages of those who had no balanced meal each day were $71.3 \%$ for group A and $59.3 \%$ for group B $(p<0.001)$.

Jpn. J. Nutr. Diet., 61 (1) $47 \sim 54$ (2003)

Key word : fast foods, young people, reasons for eating, balanced meal

は じめに

食生活をとりまく社会環境の変化は, 人びとの食生活 に対する意識の変化を背景として, 外食, 加工食品の利
用など，家庭に代わって企業が調理を行う，いわゆる食 の外部化を進行させている。粉務庁の家計調查 ${ }^{11}$ によ ると，食料費に占める外食費の割合は $17 \%$ になり，生

キーワード：ファーストフード，若年者層，利用する理由，きちんとした食事

（連絡先：浅野真智子 守口市藤田町 6-21-57 電話 06-6902-0791) 
鮮食品・穀類が占める割合が減少し, 全体の 3 分の 2 近 くが加工食品, 外食という状況である。食事づくりの面 からみると, 家庭での主な調理担当者である主婦の有職 率が高くなり，家庭での食事の準備に費やす時間が少な くなった。その結果, 食事づくりに利便性, 簡便性が重 要視されるようになり,手づくり料理は減少傾向にある。 一方, 食べる側でも従来のような, 家族がそろって, 決 まった時刻に，決められた内容のものを食べるという食 事風景が変化し，特に若年者層に，好きな時に，好きな ものを，好きなだけ，好きなように食べるという特徴が みられるようになった。家族 1 人ひとりの生活時間の違 いが個食や孤食，ファーストフードやコンビニエンス． ストアの利用増加に関連していると考えられる。

世界中で広がりをみせているファーストフードは，わ が国でも若年者層を対象に大量に販売されており, 安価 で均質な食べ物として受け入れられている。また，外食 の機会は幼児期から成長期の子どもにとっても，働く母 親の増加や家族サービスのための雲囲気づくりなど, 時 代に対応して增加傾向がみられる。その一方で, 味覚が 形成される時期に統一した味に慣れ, 様々な味の体験不

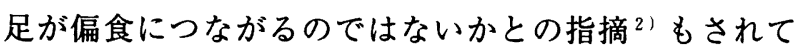
いる。食生活をめぐる目まぐるしい変化の方向は望まし いものから掛け離れたものになるのではないかとの懸念 を持ち, 若年者層の啫好や摂食内容, 摂食形態がどのよ うに変化しつつあるか知る手脚かりとして, ファースト フードの利用に着目し, 大学生, 高校生, 中学生, 小学 生が「いつ」,「どこで」,「誰と」,「何を」どのように利 用しているかについて調查を実施し，外部化された食生 活の影響について検討した。また, 併せて調査前日の食 事内容を調査し, ファーストフードの利用の多少を軸に 拱食内容, 掑食形態等について検討した。

\section{方法}

\section{1. 調査対象および調査時期}

対象者は, 大阪府下の大学, 短期大学, 専門学校に在 学する学生および学生の周辺に住む人びとの中から抽出 した。調査員である学生には, 調査対象者の性, 大学生, 高校生, 中学生, 小学生 $5 \sim 6$ 年生の年齢階層を指定し て, 合わせて 1,600 人を対象に, 自己記入式による質問 用紙を用いたアンケート調査を留め置き方式にて実施し た。調查時期は平成 12 年 10 月から 11 月。

\section{2. 調查項目}

(1) 家族状況

調查対象者からみた同居家族を 2 世代, 3 世代, 1 人 暮らし，その他（兄弟同居など）に区分した。

（2）朝食欠食と外食の頻度

「ほとんどない」,「月 $1 \sim 2$ 回」,「週 $1 \sim 2$ 回」,「週
$3 \sim 4$ 回」,「毎日」のいずれか 1 項目を選択させた。

（3）家族がそろう食事の頻度

朝食, 夕食別に「ほとんどない」,「月 $1 \sim 2$ 回」,「週 $1 \sim 2$ 回」,「週 3〜4回」,「毎日」のいずれか 1 項目を 選択させた。

（4）ファーストフードの利用頻度と利用理由

利用頻度について，「ほとんどない」,「月 $1 \sim 2$ 回」, 「週 $1 \sim 2$ 回」,「週 $3 \sim 4$ 回」,「毎日」のいずれか 1 項 目選択させた。利用理由は 14 項目の中から 3 項目以内 を選択する複数回答とした。

（5）10種類のファーストフードの利用状況 ハンバーガー, フライドポテト,ナゲット・から揚げ, ドーナッ，ホットドッグ，ピザ，たこ焼き，お好み焼き， 麺類, ご飯類の 10 種類の利用について, いつ, どこで, 誰と利用したか，その利用頻度拉よび利用した商品の評 価を, 味, 量, 価格について「満足」,「ふつう」,「不満」 の3段階で答えさせた。

（6）今後の利用について

「これまで以上に増える」，「少しずつではあるが增え る」,「今と変わらない」,「少しずつではあるが減る」, 「今よりかなり減る」のいずれか 1 項目を選択させた。

（7）体調について気になること

これまでに実施した若年者を対象とした調查等を参考 に, 生活リズムの乱れや偏った食事内容が誘因と考えら れる自覚症状 17 項目，すなわち「体がだるい」，「肥満 ぎみ」，「やせ過ぎ」，「食物アレルギーがある」，「便秘」， 「よく眠れない」,「味がわからない」，「手足が冷える」， 「朝のうちはーっとしている」,「いらいら怒りっぼい」, 「虫歯が多い」,「すぐ眠くなる」,「胃が重い」,「かぜを 引きやすい」,「朝起きられない」,「気力がない」,「疲れ やすい」の中から 3 項目以内を選択する複数回答とした。

（8）食生活で気になること

ふだんの食事や食生活で問題として挙げられることの 多い項目，すなわち「食事時間が不規則」,「食べ過ぎる」, 「間食が多い」,「塩分のとりすぎ」「運動不足」,「食欲 がない」,「食品数が少ない」,「外食が多い」,「油料理が 多い」,「早食い」,「好き嫌いが多い」,「食べ方が少ない」, 「調理済み食品が多い」,「野菜が少ない」,「牛乳・乳製 品がとれない」「栄養バランスが悪い」,「夕食の時間が 遅い」,「サプリメントに頼り過ぎる」,「やわらかいもの が多い」, 「欠食が多い」, 「加工食品が多い」，「肉を食べ ることが多い」「変化がない」，「1人で食べることが多 い」,「甘い飲料をとりすぎる」,「その他」の 26 項目に ついて該当するものをいくつでも選択する複数回答とし た。

（9）調查前日の食事調查

朝食, 昼食, 夕食の各食事ごとに食事時刻, 食事場所, 
一緒に食べた人，食事内容について記入させ，料理の組 み合わせをみた。朝食, 昼食, 夕食それぞれについて, 主食, 主菜, 副菜の「3 種そろった食事」,「いずれか 2 種」、「いずれか 1 種」，いずれにも入らない「その他」 に区分した。

\section{3. 集計と統計処理}

社会情報サービス社のアンケート調査集計ソフトを用 い, 年齢グループ別, 性別, ファーストフードの利用の 多少別の違いを $\chi^{2}$ 検定を用いて検定し, $p<0.05$ 末満を もって有意とした。

\section{結果}

\section{1．対象者の属性}

アンケート調査における有効回答者数は 1,432 名で, 回収率は89.5\%であった。その内訳は, 大学生 506 名 (男子 138 名, 女子 368 名), 高校生 561 名（男子 235 名, 女子 326 名), 中学生 226 名 (男子 102 名, 女子 124 名), 小学生 139 名（男子 70 名, 女子 69 名）であった。家族 状況からみると, 大学生では二世代同居 $72 \%$, 三世代 同居 $11 \%$, 大学生のみにみられた一人暮らし $16.6 \%$ (84 名), その他 $1 \%$, 高校生・中学生・小学生では二 世代同居, 三世代同居の割合に差はみられず, それぞれ 85〜86\%, 14〜15\%であった。

\section{2. ファーストフードの利用の現状}

（1）ファーストフードの利用頻度を表 1 に示す。小 学生, 中学生に比べ高校生, 大学生の利用頻度が高かっ た $(p<0.01)$ 。「ほとんど利用しない」は, 小学生で約 3 分の 1 を占めたが, 中学生, 高校生, 大学生の 3 グル ープでは 1 割強で差はみられなかった。「週 1 回以上利 用する」者の割合を表 2 に示す。女子に比べ男子にやや 多い傾向がみられたが，性別による有意な差がみられた のは大学生 $(p<0.01)$ のみであった。二世代同居, 三 世代同居, 一人暮らしなどの家族状況とファーストフー
ドの利用の関連をみたところ，「週 1 回以上利用する」 者の割合は二世代同居 $36.1 \%$ ，三世代同居 $32.1 \% ， 1$ 人 暮らし $44.0 \%$ であり，1 人暮らしがやや高かったものの 有意な差はみられなかった。

（2）ファーストフードを利用する理由を表 3 に示す。 全体でみると最も多かったのは「安い」であり, 次いで 「おいしい」，「いつでも食べられる」の順であった。大 学生, 高校生では「安い」が第 1 位で, 大学生男子 $58.5 \%$, 女子 $60.2 \%$, 高校生男子 $47.0 \%$, 女子 $48.9 \%$ で 男女差はみられなかった。中学生, 小学生では「おいし い」が第 1 位で，中学生男子 $52.9 \%$, 女子 $51.2 \%$, 小学 生男子 $65.7 \%$, 女子 $49.2 \%$ あ゙あった。大学生, 高校生, 中学生では上位 3 位までに挙げられた理由は重なってい たが，小学生では第 2 位「楽しみ」, 第 3 位「自分の好 みに合う」の順となった。

表 1 ファーストフードの利用頻度

(\%)

大学生 高校生 中学生 小学生 $(n=502)(n=558)(n=226)(n=139)$

\begin{tabular}{|c|c|c|c|c|}
\hline ほとんど利用しない & 15.1 & 11.8 & 17.3 & 33.8 \\
\hline 月 1 ～ 2 回利用 & 42.4 & 46.4 & 59.7 & 53.2 \\
\hline 週 $1 \sim 2$ 回利用 & 32.9 & 33.5 & 20.8 & 12.2 \\
\hline 週 $3 \sim 4$ 回利用 & 8.6 & 7.5 & 2.2 & 0.7 \\
\hline ほとんど毎日利用 & 1.0 & 0.7 & 0 & 0 \\
\hline
\end{tabular}

$\chi^{2}$ 検定, $p<0.01$

表 2 ファーストフードを週 1 回以上利用する者

\begin{tabular}{llll}
\hline & 全体 & 男子 & 女子 \\
\hline 大学生 $(n=502)$ & 42.4 & 58.0 & 36.6 \\
高校生 $(n=558)$ & 41.7 & 44.1 & 40.1 \\
中学生 $(n=226)$ & 23.0 & 25.5 & 21.0 \\
小学生 $(n=139)$ & 12.9 & 15.7 & 10.1 \\
\hline
\end{tabular}

$\chi^{2}$ 検定, $p<0.01$ (vs 女子)

表 3 ファーストフードの利用理由

\begin{tabular}{lccccc}
\hline & $\begin{array}{c}\text { 全体 } \\
(n=1,409)\end{array}$ & $\begin{array}{c}\text { 大学生 } \\
(n=497)\end{array}$ & $\begin{array}{c}\text { 高校生 } \\
(n=557)\end{array}$ & $\begin{array}{c}\text { 中学生 } \\
(n=223)\end{array}$ & $\begin{array}{c}\text { 小学生 } \\
(n=132)\end{array}$ \\
\hline 安い & 47.2 & $(1)$ & $(1)$ & $(2)$ & $(5)$ \\
おいしい & 40.3 & $(3)$ & $(2)$ & $(1)$ & $(1)$ \\
いつでも食べられる & 29.7 & $(2)$ & $(3)$ & $(3)$ & \\
お腹が空く & 23.2 & & $(4)$ & $(5)$ & \\
早い & 22.8 & $(4)$ & & & \\
自分の好みに合う & 22.6 & & $(5)$ & $(4)$ & $(3)$ \\
近くにある & 20.0 & $(5)$ & & & $(4)$ \\
持ち㷌りできる & 16.3 & & & & (5) \\
作るのがめんどう & 11.8 & & & & (2) \\
楽しみ & 11.6 & & & &
\end{tabular}

注）複数回答, ○の中は順位 
表 410 種類のファーストフードの利用経験の有無と利用頻度

(\%)

\begin{tabular}{|c|c|c|c|c|c|c|c|c|c|c|}
\hline & \multicolumn{2}{|c|}{ ハンバーガー } & \multicolumn{2}{|c|}{ フライドポテト } & \multicolumn{2}{|c|}{ ナゲット・から揚げ } & \multicolumn{2}{|c|}{ ドーナツ } & \multicolumn{2}{|c|}{ ホットドッグ } \\
\hline & 大・高 & 小・中 & 大・高 & 小・中 & 大·高 & 小・中 & 大・高 & 小・中 & 大·高 & 小・中 \\
\hline 利用経験あり & 90.2 & 90.1 & 84.8 & 87.1 & 63.5 & 64.9 & 32.2 & 58.9 & 26.6 & 24.4 \\
\hline \multicolumn{11}{|l|}{ 〈利用頻度〉 } \\
\hline & $(n=949)$ & $(n=324)$ & $(n=887)$ & $(n=314)$ & $(n=656)$ & $(n=233)$ & $(n=614)$ & $(n=214)$ & $(n=277)$ & $(n=88)$ \\
\hline $\begin{array}{l}\text { ほとんどない } \\
\text { 月1〜2回 }\end{array}$ & $\begin{array}{r}6.0 \\
64.0\end{array}$ & $\begin{array}{r}9.3 \\
77.2\end{array}$ & $\begin{array}{r}6.7 \\
63.2\end{array}$ & $\begin{array}{r}9.6 \\
79.0\end{array}$ & $\begin{array}{r}2.8 \\
637\end{array}$ & $\begin{array}{l}17.2 \\
691\end{array}$ & $\begin{array}{l}13.8 \\
73.9\end{array}$ & $\begin{array}{l}16.8 \\
75.7\end{array}$ & $\begin{array}{l}38.3 \\
55.2\end{array}$ & $\begin{array}{l}35.2 \\
53.4\end{array}$ \\
\hline 週 1 ～ 2 回 & 27.7 & 12.7 & 27.2 & 11.1 & 20.7 & 12.9 & 11.1 & 5.6 & 5.8 & 8.0 \\
\hline 週 3 ～ 4 回 & 3.2 & 0.6 & 2.8 & 0 & 2.4 & 0.9 & 0.8 & 1.4 & 0.7 & 3.4 \\
\hline ほとんど毎日 & 0.2 & 0.3 & 0.1 & 0.3 & 0.3 & 0 & 0.3 & 0.5 & 0 & 0 \\
\hline \multirow[t]{3}{*}{ 有意確率（ $\chi^{2}$ 検定） } & \multicolumn{2}{|c|}{$p<0.01$} & \multicolumn{2}{|c|}{$p<0.01$} & \multicolumn{2}{|c|}{$p<0.05$} & \multicolumn{2}{|c|}{ NS } & \multicolumn{2}{|c|}{ NS } \\
\hline & \multicolumn{2}{|c|}{ ピザ } & \multicolumn{2}{|c|}{ たこ焼き } & \multicolumn{2}{|c|}{ お好み焼き } & \multicolumn{2}{|c|}{ 麺類 } & \multicolumn{2}{|c|}{ ご飯類 } \\
\hline & 大・高 & 小・中 & 大・高 & 小.中 & 大・高 & 小.中 & 大・高 & 小・中 & 大・高 & 小・中 \\
\hline 利用経験あり & 46.9 & 49.0 & 62.1 & 58.4 & 49.9 & 43.8 & 65.7 & 51.2 & 70.7 & 58.9 \\
\hline \multicolumn{11}{|l|}{ 〈利用頻度〉 } \\
\hline & $(n=483)$ & $(n=176)$ & $(n=651)$ & $(n=206)$ & $(n=522)$ & $(n=156)$ & $(n=688)$ & $(n=184)$ & $(n=739)$ & $(n=211)$ \\
\hline ほとんどない & 23.2 & 28.4 & 12.1 & 13.6 & 15.0 & 17.3 & 11.5 & 14.7 & 10.3 & 14.7 \\
\hline 月 1 ～ 2 回 & 71.0 & 66.5 & 69.6 & 70.9 & 73.2 & 73.1 & 61.2 & 69.0 & 59.0 & 64.5 \\
\hline 週 1 〜 2 回 & 5.0 & 5.1 & 16.1 & 14.6 & 9.8 & 9.6 & 23.7 & 13.6 & 16.1 & 12.8 \\
\hline 週 3〜 4 回 & 0.6 & 0 & 2.0 & 1.0 & 0.8 & 0 & 2.9 & 2.7 & 5.5 & 0 \\
\hline ほとんど毎日 & 0.2 & 0 & 0.2 & 0 & 0.4 & 0 & 0.7 & 0 & 9.1 & 8.1 \\
\hline 有意確率（ $\chi^{2}$ 検定） & \multicolumn{2}{|c|}{ NS } & \multicolumn{2}{|c|}{ NS } & \multicolumn{2}{|c|}{ NS } & \multicolumn{2}{|c|}{$p<0.05$} & \multicolumn{2}{|c|}{$p<0.01$} \\
\hline
\end{tabular}

表 5 平日の 10 種類のファーストフードの利用状況

(\%)

\begin{tabular}{|c|c|c|c|c|c|c|c|c|c|c|c|}
\hline & & \multicolumn{2}{|c|}{ ハンバーガー } & \multicolumn{2}{|c|}{ フライドポテト } & \multicolumn{2}{|c|}{ ナゲット・から揚げ } & \multicolumn{2}{|c|}{ ドーナツ } & \multicolumn{2}{|c|}{ ホットドッグ } \\
\hline & & $\begin{array}{r}\text { 大 } \cdot \text { 高 } \\
(n=598)\end{array}$ & $\begin{array}{l}\text { 小.中 } \\
(n=98)\end{array}$ & $\begin{array}{c}\text { 大 } \cdot \text { 高 } \\
(n=551)\end{array}$ & $\begin{array}{l}\text { 小.中 } \\
(n=92)\end{array}$ & $\begin{array}{c}\text { 大 } \cdot \text { 高 } \\
(n=405)\end{array}$ & $\begin{array}{l}\text { 小・中 } \\
(n=82)\end{array}$ & $\begin{array}{c}\text { 大 } \cdot \text { 高 } \\
(n=406)\end{array}$ & $\begin{array}{l}\text { 小・中 } \\
(n=106)\end{array}$ & $\begin{array}{c}\text { 大・高 } \\
(n=162)\end{array}$ & $\begin{array}{l}\text { 小・中 } \\
(n=33)\end{array}$ \\
\hline \multirow{2}{*}{ w } & 朝 食 & 3.0 & 3.1 & 2.0 & 1.1 & 2.7 & 1.2 & 13.3 & 22.6 & 22.8 & 33.3 \\
\hline & 昼 食 & 54.3 & 37.8 & 55.7 & 30.4 & 51.6 & 35.4 & 15.0 & 8.5 & 21.0 & 27.3 \\
\hline \multirow[t]{2}{*}{ つ } & 夕 食 & 14.7 & 7.1 & 12.5 & 10.9 & 17.5 & 26.8 & 2.7 & 1.9 & 3.7 & 3.0 \\
\hline & 間 食 & 47.0 & 54.1 & 48.8 & 62.0 & 44.7 & 39.0 & 77.6 & 75.5 & 42.0 & 36.4 \\
\hline ど & 内 & 95.5 & 91.8 & 92.7 & 82.6 & 81.0 & 59.8 & 69.0 & 49.1 & 52.5 & 27.3 \\
\hline$\equiv$ & 外 & 5.0 & 3.1 & 5.6 & 4.3 & 7.4 & 6.1 & 3.9 & 3.8 & 18.5 & 27.3 \\
\hline で & 自 宅 & 8.9 & 14.3 & 13.8 & 18.5 & 23.0 & 35.4 & 32.0 & 49.1 & 37.7 & 42.4 \\
\hline \multirow{7}{*}{$\begin{array}{l}\text { だ } \\
れ \\
\text { と }\end{array}$} & & 13.4 & 51.0 & 16.5 & 47.8 & 18.8 & 57.3 & 37.7 & 70.8 & 22.8 & 48.5 \\
\hline & 友人 & 79.6 & 43.9 & 80.0 & 47.8 & 76.0 & 35.4 & 56.7 & 14.2 & 57.4 & 30.3 \\
\hline & 1 人 & 13.9 & 15.3 & 12.3 & 13.0 & 14.1 & 9.8 & 15.8 & 17.0 & 21.6 & 27.3 \\
\hline & その他 & 3.5 & 0 & 3.6 & 1.1 & 2.2 & 0 & 2.2 & 2.8 & 4.3 & 0 \\
\hline & & \multicolumn{2}{|c|}{ ピザ } & \multicolumn{2}{|c|}{ たこ焼き } & \multicolumn{2}{|c|}{ お好み焼き } & \multicolumn{2}{|c|}{ 缅類 } & \multicolumn{2}{|c|}{ ご飯類 } \\
\hline & & 大·高 & 小・中 & 大·高 & 小・中 & 大·高 & 小・中 & 大·高 & 小・中 & 大・高 & 小・中 \\
\hline & & $(n=239)$ & $(n=71)$ & $(n=460)$ & $(n=114)$ & $(n=333)$ & $(n=77)$ & $(n=461)$ & $(n=94)$ & $(n=492)$ & $(n=98)$ \\
\hline \multirow{4}{*}{$\begin{array}{l}w \\
\supset\end{array}$} & 朝 & 6.3 & 8.5 & 0.9 & 0.9 & 1.8 & 0 & 3.3 & 4.3 & 11.4 & 8.2 \\
\hline & 食 & 25.1 & 12.7 & 32.4 & 20.2 & 42.3 & 27.3 & 56.6 & 40.4 & 54.5 & 36.7 \\
\hline & 食 & 59.8 & 56.3 & 10.9 & 11.4 & 58.6 & 62.3 & 51.6 & 51.1 & 53.5 & 65.3 \\
\hline & 間 食 & 21.8 & 28.2 & 66.3 & 71.9 & 9.6 & 13.0 & 9.5 & 12.8 & 7.7 & 6.1 \\
\hline \multirow{3}{*}{ ぞ } & & 28.5 & 25.4 & 9.6 & 7.9 & 18.0 & 10.4 & 49.2 & 36.2 & 51.8 & 26.5 \\
\hline & 野 & 2.5 & 1.4 & 48.5 & 36.0 & 15.3 & 6.5 & 6.1 & 2.1 & 4.1 & 6.1 \\
\hline & 自 宅 & 75.3 & 76.1 & 50.0 & 55.3 & 71.8 & 83.1 & 56.2 & 62.8 & 53.7 & 68.4 \\
\hline \multirow{4}{*}{$\begin{array}{l}\text { だ } \\
\text { と } \\
\text { と }\end{array}$} & & 66.1 & 83.1 & 34.1 & 54.4 & 61.6 & 80.5 & 43.6 & 78.7 & 12.2 & 88.8 \\
\hline & 友人 & 35.1 & 4.2 & 63.5 & 38.6 & 15.3 & 10.4 & 52.9 & 12.8 & 51.4 & 10.2 \\
\hline & 1 人 & 7.1 & 11.3 & 16.7 & 9.6 & 8.1 & 5.2 & 15.4 & 11.7 & 12.2 & 5.1 \\
\hline & その他 & 3.3 & 2.8 & 2.6 & 1.8 & 3.3 & 2.6 & 3.9 & 0 & 6.9 & 1.0 \\
\hline
\end{tabular}

注）複数回答 
表 6 ファーストフードの今後の利用

(\%)

\begin{tabular}{lccccc}
\hline & 全体 & 大学生 & 高校生 & 中学生 & 小学生 \\
\hline 今後増える & 27.5 & 18.5 & 32.8 & 34.1 & 27.9 \\
今と変わらない & 61.1 & 65.8 & 56.4 & 58.3 & 68.4 \\
今より減る & 11.4 & 15.7 & 10.8 & 7.6 & 3.8 \\
\hline
\end{tabular}

$\chi^{2}$ 検定, $p<0.01$

（3）10種類のファーストフードの利用経験の有無 と利用頻度を表 4 に示す。自分の自由意志で外食内容を 選ぶことができる大学生・高校生グループ1,068名と, 保護者の関わりが大きい小.中学生グループ 364 名の 2 グルーブに分けて検討した。

利用経験についてみると, ハンバーガー, フライドポ テトの利用経験がある者は 8 割以上にのぼり, 利用が 5 割に满たなかったのはドーナッ, ホットドッグ, ピザ, お好み焼きであった。2 2 グループの間で違いがみられた のはドーナツ, 麺類, ご飯類で, ドーナツは小・中学生 グループで高く, 麺類, ご飯類は大学生・高校生グルー プで高い傾向がみられた。性別による利用経験の有無に ついても検討したところ, 差がみられたのはドーナツの みで，利用経験がある割合が男子の $48.4 \% に$ に比べ, 女子 は $64.9 \%$ と高かった $(p<0.01)$ 。

大学生・高校生と小・中学生との 2 グループに分けて 利用頻度をみた。ハンバーガー $(p<0.01)$, フライドポ テト $(p<0.01)$, ナゲット・から揚げ $(p<0.05)$, 麺類 $(p<0.05)$, ご飯類 $(p<0.01)$ で, 大学生・高校生グル 一プの利用頻度が高く, 週 1 回以上利用する者が 2 割を 越えていた。

（4）10種類のファーストフードの利用状況を平日 と休日に分けて質問した（複数回答）。平日の結果を表 5 に示す。「いつ」利用するかという設問では, 小・中 学生ではハンバーガー, フライドポテト, ナゲット・か ら揚げは間食, 大学生・高校生では昼食での利用が多く, ドーナツ，ホットドッグ，たこ焼きは両グループとも間 食での利用が，ピザ，お好み焼きは両グループとも夕食 での利用が多い傾向がみられた。缅類，ご飯類は，小・ 中学生では夕食で, 大学生・高校生では昼食と夕食での 利用が多い傾向がみられた。一人暮らしの大学生につい て検討したが，ホットドッグを昼食に $(58.8 \%)$ ，ハン バーガーを夕食に $(29.8 \%)$ 利用する割合がやや高い傾 向がみられた他は, 他の大学生と差がみられなかった。

休日では平日に比べ, ハンバーガー, フライドポテト, ナゲット・から揚げ，ホットドッグが昼食での利用が増 え，間食での利用が減る傾向がみられた。また，ピザ， お好み焼き，缅類，ご飯類は夕食での利用が多い傾向が みられた。
表 7 ファーストフードの利用の多少と朝食欠食

$(\%)$

\begin{tabular}{|c|c|c|}
\hline \multirow[b]{2}{*}{ 欠 食 } & \multicolumn{2}{|c|}{ 利 用 } \\
\hline & $\begin{array}{c}\text { 多い群 } \\
(n=516)\end{array}$ & $\begin{array}{l}\text { 少ない群 } \\
(n=906)\end{array}$ \\
\hline ほとんどない & 48.4 & 69.3 \\
\hline 月 $1 \sim 2$ 回 & 7.4 & 6.2 \\
\hline 週 $1 \sim 2$ 回 & 17.5 & 9.9 \\
\hline 週 $3 \sim 4$ 回 & 11.9 & 7.3 \\
\hline ほとんど毎日 & 14.8 & 7.3 \\
\hline
\end{tabular}

$\chi^{2}$ 検定, $p<0.01$

「食べる場所」として，ファーストフード店やファミ リーレストランなどの店内，野外，自宅に持ち帰る，に 分けてみると, 店内で食べるのは, ハンバーガー, フラ イドポテト, ナゲット・から揚げ, ドーナッ, ホットド ッグで多く，他は自宅に持ち帰って食べる者が多い傾向 がみられた。小・中学生グループで自宅に持ち帰って食 ベる割合がやや多い傾向がみられた。野外で食べる割合 が高かったのはたこ焼きで，大学生・高校生 $48.5 \%$, 小・中学生 $36.0 \%$ あった。

「誰と利用するか」の問では, 小・中学生ではいずれ も「家族と一緒に利用する」が多く, 大学生・高校生で はピザ，お好み焼きは「家族と一緒に利用する」，その 他は「友人と利用する」，が多い傾向がみられた。

利用しての評価を「満足」,「ふつう」, 「不満」の 3 段 階できいた。全体でみると，味については「満足」，「ふ

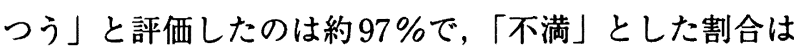
数\%と低かった。量についても 9 割が「ふつう」以上と し，不満とした割合が高かったナゲット・から揚げ $(17.6 \%)$ ，フライドポテト $(10.4 \%)$ ，ホットドッグ (10.0\%) を除いて 1 割に満たなかった。価格について も 8 割が「ふつう」以上の評価をしたが, ピザ (40.6\%), ナゲット・から揚げ $(28.7 \%)$ で不満の割合が高かった。

（5）ファーストフードの今後の利用について表 $6 に$ 示す。全体の $61.1 \%$ 「今と変わらない」としたが, 「今後增える」が $27.5 \%$ ，「隇る」の $11.4 \%$ 大きく上 回った。内訳をみると，「今後増える」と答えた割合は 大学生 $18.5 \%$ に比べ, 高校生 $32.8 \%$, 中学生 $34.1 \%$, 小 学生 $27.9 \%$ で年齢の若いグループで高くなった（ $p<$ 0.01）。性別でみると男性（534名）では「今後増える」 が $28.3 \%$ ，「変わらない」 $63.7 \%$ ，「今より減る」 $8.1 \%$ であったのに対し，女性（873名）では「今後増える」 $27.0 \%$,「今と変わらない」59.6\%，「今より隇る」 $13.4 \%$ と性の方に「隇る」と答えた割合が高かった $(p<0.01)$ 。 
表 8 ファーストフードの利用の多少と家族と一緒の食事

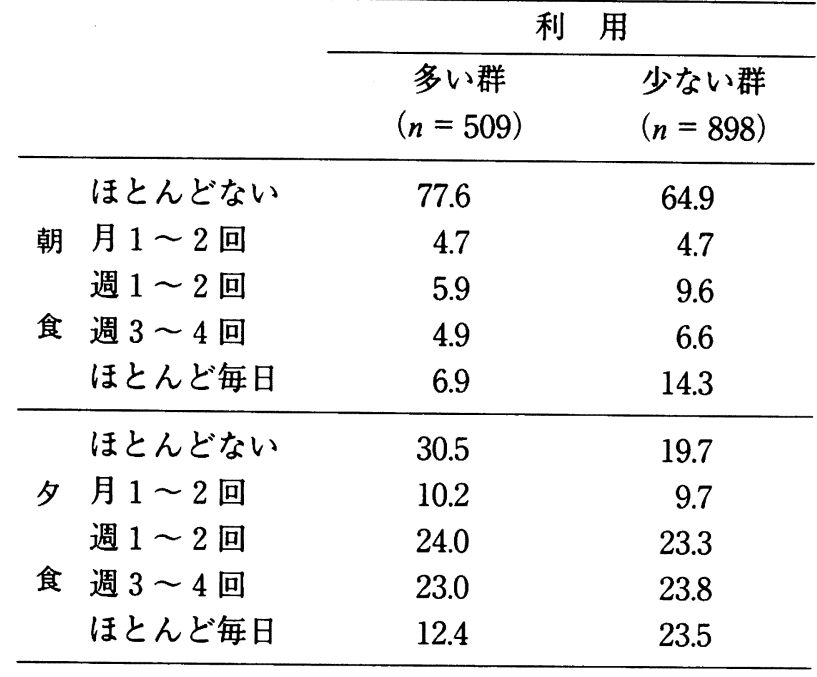

$\chi^{2}$ 検定, $p<0.01$

\section{3.ファーストフードの利用の多少が食生活に及ぼす} 影㓻

ファーストフードの利用が「ほとんどない」と「月 1 〜 2 回」を少ない群に,「週 1〜2 回」,「週 3〜 4 回」, 「ほとんど毎日」を多い群に二分し, 利用の多少が若者 の食生活に及ほす影響について検討した。

（1）ファーストフード利用の多少と朝食欠食

朝食をほとんど久食しない者の割合は, 小学生 $83.3 \%$, 中学生 $68.8 \%$, 高校生 $62.9 \%$, 大学生 $51.5 \%$ で, 年齢の 高いグループになるほど減少した $(p<0.01)$ 。性別でみ ると,ほとんど久食しない者の割合は男子 $58.9 \%$ に比べ， 女子 $63.1 \%$ と女子の欠食率が低かった $(p<0.01)$ 。ファ ーストフードの利用の多少と朝食欠食状況を表 7 に示し た。朝食を欠食しない者は利用が少ない群に多かった $(p<0.01)$ 。なかでも小学生の朝食欠食率は低く, ファ ーストフードの利用が少ない者が $89 \%$ を占めた。

（2）ファーストフードの利用の多少と家族と一緒の 食事回数

ファーストフードの利用の多い群と少ない群の, 家族 と一緒の食事回数を表 8 に示した。朝食, 夕食ともに家 族と一緒の食事回数はファーストフードの利用が少ない 群に多かった $(p<0.01)$ 。

（3）体のことで気になることと食生活で気になること

「体のことで気になること」の第 1 位は，いずれのグ ループにおいても, 男子で「朝起きられない」, 女子で は「肥満ぎみ」であった。ファーストフードの利用が多 い群で，朝起きられない $(37.0 \%)$ ，すぐ眠くなる $(29.1 \%)$ ，体がだるい $(28.7 \%)$ などの出現率が高い傾 向がみられた（表 9 )。また，「食生活で気になること」 では，食事時刻が不規則 $(49.9 \%)$ ，栄養のバランスが 悪い $(39.4 \%)$, 加工食品が多い $(34.1 \%)$ ，夕食の時間
表 9 ファーストフードの利用の多少と体調

\begin{tabular}{lcc}
\hline & \multicolumn{2}{c}{ 利 } \\
\cline { 2 - 3 } & $\begin{array}{c}\text { 多い用 } \\
(n=478)\end{array}$ & $\begin{array}{r}\text { 少ない群 } \\
(n=817)\end{array}$ \\
\hline 朝起きられない & 37.0 & 28.4 \\
すぐ眠くなる & 29.1 & 22.0 \\
肥满ぎみ & 28.7 & 28.5 \\
体がだるい & 26.4 & 18.8 \\
疲れやすい & 23.6 & 21.4 \\
いらいら怒りっぽい & 19.7 & 16.4 \\
朝のうちほっとしている 18.0 & 17.7
\end{tabular}

注）複数回答, 上位 7 位まで

$$
\text { 表10 ファーストフードの利用と }
$$

食生活で気になること

\begin{tabular}{lcc}
\hline & \multicolumn{2}{c}{$(\%)$} \\
\cline { 2 - 3 } & $\begin{array}{c}\text { 多い利 } \\
(n=497)\end{array}$ & $\begin{array}{c}\text { 用 } \\
(n=858)\end{array}$ \\
\hline 食事時間が不規則 & 49.9 & 29.5 \\
食べ過ぎる & 40.8 & 38.9 \\
栄養のバランスが悪い & 39.4 & 24.8 \\
間食が多い & 38.2 & 32.5 \\
野菜が少ない & 35.6 & 29.6 \\
加工食品が多い & 34.1 & 17.1 \\
夕食の時間が遅い & 31.8 & 22.5 \\
\hline
\end{tabular}

注） 複数回答, 上位 7 位まで

が遅い $(31.8 \%)$ で，利用の少ない群に比べ出現率が高 い傾向がみられた（表 10）。

現在の食生活を改善したいと思っているのは, 利用が 多い群 80.9\%（411/508名），少ない群 73.0\%（660/904 名）で, 利用の多い群でやや高い傾向がみられた。改善 したい項目を利用の多い群と少ない群別にみると，腹八 分目がそれぞれ $43.5 \% ， 48.0 \%$ ，間食・夜食を減らす $49.8 \%, 41.9 \%$, 栄養のバランス $46.9 \%, 36.1 \%$ あっ た。また, 利用の多い群では規則正しい食事時間を挙げ たものが $40.1 \%$ 占めた。

\section{4.ファーストフードの利用の多少と食事内容}

調査前日の食事記録（調査前日が祝日・休日になった ものを除く）から, 各食事について,「いつ」,「どこで」, 「誰と」，「何を」食べたかを 4 グルーブ別にみた。朝食 欠食者は大学生 $20.3 \%(89 / 438$ 名)，高校生 $16.6 \%$ (74/446名), 中学生 $12.1 \%$ (22/182名), 小学生 $2.5 \%$ （3/118名）であった。朝食時刻は平日であることから， 通学前に食べていた。大学生で 9 時以後に食事を摂って いる者が7.1\%あった。食べる場所では自宅外が大学生 の $8.0 \%$, 高校生の $3.2 \%$ $\%$ みたた。朝食を 1 人で食べ るのは大学生 $72.7 \%$, 高校生 $59.1 \%$, 中学生 $50.3 \%$, 小 
学生 $17.4 \%$ \%゙あった。昼食はほとんどが決まった時間に 摂っており, 平日でもあるので, 学校で友人と一緒に食 べていた。夕食を 20 時までに済ませる小学生が $85.5 \%$, 中学生 $70.7 \%$, 高校生 $56.1 \%$, 大学生 $48.9 \%$ と年齢が高 いグループになるほど夕食時間が遅い者が増加した $(p<0.01)$ 。夕食を自宅外で搨ったのは大学生で $21.8 \%$, 高校生で $9.5 \%$ あり，1 人で食べた者は大学生の $35.8 \%$, 高校生の $27.3 \%$, 中学生の $21.1 \%$, 小学生の $5.9 \%$ あっ た。

食事内容については, 料理の組み合わせを主食・主 菜・副菜を食事の核となる料理 ${ }^{3)}$ として,「 3 種そろっ た食事」,「いずれか 2 種」,「いずれか 1 種」,「その他」 に区分して食事の偏りをみた。「その他」には飲み物, 果物, 菓子などが含まれる。ファーストフードの利用の 多い群と少ない群の料理の組み合わせを表 11 に示す。 朝食, 昼食, 夕食ともに利用の少ない群に 3 種そろった 食事の出現率が高かった $(p<0.01)$ 。また, 表 12 に示 すように 1 日のうちで 3 種そろった食事が 1 回もないの は, 利用の多い群で $71.3 \%$, 少ない群の $59.3 \%$ に比べ 高かった $(p<0.001)$ 。

\section{考察}

食生活をとりまく環境の変化は, 本来のような, 家庭 内で調理され，家庭内で家族が食卓を囲んで集うという 食事（内食）から，コンビニエンス・ストアやテイクア ウト店で，できあいの食事を購入して済ませる食事（中 食), ファーストフード店やファミリーレストランでの 「外食」と, 食事づくりの簡便化傾向に拍車をかけてい る。1988年に, 食に関わる専門家を網羅して実施され た食生活の変化の方向を探る予測調査 ${ }^{4)}$ でも, 外食, 持 ち帰り弁当や調理済み食品の利用は今後さらに増加して いくと予測され, 外食は場所, 時間に制限されずに食事 ができ, また, 家庭内食とは全く異なる環境, 雲囲気で 食事ができる点で, 食事形態を大きく恋革させる要素を もっていると述べられている。著者等は食生活の変化を 調理済み食品の利用実態5、6)，コンビニエンス・ストア の利用実態 のファーストフードの利用実態についての調查結果から も若年者層の多くが利用した経験を有し，表 3 に示した ように，利用する理由に「安い」，「おいしい」,「いつで も食べられる」が上位に挙げられ, 食生活への浸透ぶり がうかがえた。また，ファーストフードの今後の利用が 「今と変わらない」，または「増加する」と答えた割合が 「減少する」を大きく上回っていた。高校生, 中学生で 増加すると答えた割合がそれぞれ $32.8 \%, 34.1 \%$ 高く， 今後も増える傾向にあると考えられる。

今回の調查対象者全体についてみると, 食生活で気に
表11 ファーストフードの利用の多少と料理の組み合わせ

$(\%)$

\begin{tabular}{|c|c|c|c|}
\hline & \multicolumn{2}{|c|}{ 利 用 } \\
\hline & & 多い群 & 少ない群 \\
\hline \multirow{3}{*}{ 朝 } & & $(n=369)$ & $(n=784)$ \\
\hline & 3 種そろった食事 & 1.1 & 5.2 \\
\hline & いずれか 2 種 & 43.9 & 46.7 \\
\hline \multirow[t]{3}{*}{ 食 } & いずれか 1 種 & 48.0 & 43.5 \\
\hline & その他 & 7.1 & 4.6 \\
\hline & & $(n=482)$ & $(n=863)$ \\
\hline \multirow[t]{2}{*}{ 昼 } & 3 種そろった食事 & 12.2 & 19.6 \\
\hline & いずれか 2 種 & 31.5 & 38.2 \\
\hline \multirow[t]{3}{*}{ 食 } & いずれか 1 種 & 55.6 & 41.6 \\
\hline & その他 & 0.6 & 0.5 \\
\hline & & $(n=484)$ & $(n=866)$ \\
\hline \multirow[t]{2}{*}{ 夕 } & 3 種そろった食事 & 21.7 & 27.8 \\
\hline & いずれか 2 種 & 40.3 & 43.7 \\
\hline \multirow[t]{2}{*}{ 食 } & いずれか 1 種 & 37.4 & 28.3 \\
\hline & その他 & 0.6 & 0.3 \\
\hline
\end{tabular}

注）欠食を除く。 $\chi^{2}$ 検定, $p<0.01$

表12 ファーストフードの利用と 3 種そろった食事の回数

\begin{tabular}{cccc}
\hline & & \multicolumn{2}{c}{ 利 } \\
\cline { 3 - 4 } & & $\begin{array}{c}\text { 多い群 } \\
(n=505)\end{array}$ & $\begin{array}{c}\text { 少ない群 } \\
(n=892)\end{array}$ \\
\hline な & し & 71.3 & 59.3 \\
1 & 回 & 24.4 & 32.1 \\
2 & 回 & 4.4 & 7.7 \\
3 & 回 & 0 & 0.9 \\
\hline
\end{tabular}

$\chi^{2}$ 検定, $p<0.001$

なることとして「食べ過ぎる」を挙げたのは $39.6 \%$ ， 「間食が多い」34.5\%，「甘い飲料をとりすぎる」 $22.5 \%$ であった。ファーストフードの発祥の地, アメリカでは 女性の労働人口の増加に伴ってその利用が増え, 今日で は, 食費の半分に当たる額が外食費に，それも主として ファーストフード店に支払われているという ${ }^{81}$ 。外食が 食事の中心になることで子どもに与える影響について太 田 ${ }^{2)}$ は，統一された味の体験が多くなり，味覚形成の 後退や栄養の点では明らかに, 野菜不足, 脂質過剩, 塩 分過剰が考えられ，食物繊維の不足を招く。その結果， 肥満が増加し，生活習慣病にかかる率も増加する，と懸 念している。平成 12 年国民栄養調査結果 ${ }^{9 \prime}$ からも若者 の間で「孤食」が広がりをみせるなか，「1 日に最低 1 食は 30 分以上かけて，2 人以上で楽しく食事をしてい る」者の割合は 20 歳代男性の $49.9 \%$ と半数程度であっ た。女性は年代別でも最も低い 20 歳代でも $66.6 \%$ あ, 
女性に比べて男性の栄養や食事への関心の低さが目立 つ。また，健康づくりのため栄盖や食事について考える かどうかという設問に「まったく」，「あまり」を合わせ て考えない者が若年層で目立ち, 男性の $15 \sim 29$ 歳では 約 5 割, 女性でも約 4 割であった。今回の調査でも食生 活や体調で気になることとして, 食べ過ぎる, 間食が多 い, 野菜が少ない, 肉を多く食べるなど栄養のバランス が悪いことを挙げ, 肥満気味, 朝起きられない, すぐ眠 くなる，疲れやすい，体がだるい，いらいら怒りっぼい と感じている割合がファーストフードを多く利用してい る者に多い傾向がみられた。いつでも，どこでも，好き なものを，好きなだけ食べるという食生活を続けること は健康を損ない, 画一的な味で食べ物本来の味がわから なくなり, 食べる楽しみ, 味わう楽しみが失われる危険 性もある。健康日本 $21^{10)}$ に掲げられている量, 質とも にきちんとした食事をする者の割合を増加させるために 「1 日最低 1 食, きちんとした食事を, 決まった時間に, 家族等 2 人以上で楽しく, 30 分以上かけてとる」ことを 目標に食への意識を高めていくことが急務と考えられた。

\section{ま と め}

若年者層のファーストフードの利用実態について調查 し，食生活に及ほす影響について検討した。

1）ファーストフードを週 1 回以上利用する者は全 体の $31.6 \%$ あ, 小・中学生に比し大学生・高校生に多 く $(p<0.01)$, また, 女子に比べ男子に多い傾向がみら れた。

2）利用する理由に「安い」,「おいしい」を挙げた 者が 4 割以上を占め,「いつでも食べられる」が次いだ。 利用頻度が少なかった小学生では,「安い」に次いで 「楽しみ」が挙げられた。

3) ファーストフードの種類では，ハンバーガー, フライドポテト, ナゲット・から揚げは昼食, 間食に, ドーナッ，ホットドッグ，たこ焼きは間食に，ピザは夕 食に, お好み焼き, 曙類, ご飯類は昼食および夕食に利 用されることが多い傾向がみられた。

4 ）食べる場所については, ハンバーガー, フライ ドポテト,ナゲット・から揚げは「店内」, ピザ, お好 み焼きは「自宅」, ドーナッ, ホットドッグ, 麺類, ご 飯類は「店内」および「自宅」，たこ焼きは「自宅」お よび「野外」が多い傾向がみられた。

5）だれと利用するかの設問では，小・中学生では 「家族と一緒」が, 大学生・高校生ではピザ，お好み焼 きを除いて「友人」が多い傾向がみられた。

$6 ）$ 利用しての評価では,「味」について不満とした 者はほとんどみられなかったが,「量」ではナゲット． から揚げを，「価格」ではピザ，ナゲット・から揚げを
不满とした者の割合が高い傾向がみられた。

7 ）ファーストフードの利用が多い群で朝食の欠食 割合が高く $(p<0.01)$, 利用の少ない群で朝食・夕食と もに家族と一緒の食事の頻度が高かった $(p<0.01)$ 。

8）ファーストフードの利用が多い群で，「朝起きら れない」，「すぐ眠くなる」，「体がだるい」などの出現率 が高い傾向が，また，「食事時刻が不規則」，「栄養のバ ランスが悪い」,「夕食の時間が遅い」,「加工食品が多い」, 「野菜が少ない」の出現率が高い傾向がみられた。

9 ）料理の組み合わせで主食・主菜・副菜の 3 種そ ろった食事を摄っている割合は全体的に少なく，朝食 $3.7 \%$, 昼食 $18.9 \%$, 夕食 $25.8 \%$ であったが，いずれも ファーストフードの利用の少ない群に多くなった $(p<$ 0.01)。また， 3 種そろった食事が 1 日に 1 回もないの は利用の多い群 $71.3 \%$ ，少ない群 $59.3 \%$ と差がみられた $(p<0.001)$ 。

この論文の一部は第 48 回日本栄養改善学会学術総会 で発表した。

\section{文献}

1) 総務省統計局編：家計調査年報平成 12 年, （2001）日本統計協会, 東京

2）太田百合子：子どもの外食をどう考える？，食 生活, 96（5)，20-24（2002）

3 ）足立已幸, 針谷順子：食事パターンから食構成 を探る，食の科学， 56, 107-119（1980）

4 ）食品総合研究所：食生活の長期展望（1989）農 林統計協会, 東京

5 ）浅野真智子, 深藏紀子, 尾立純子, 瓦家千代子, 山本悦子, 伊東ソヨ子, 岡本佳子, 安田直子, 島田豊治, 難波敦子：大阪周辺での調理済み食品の利用実態, 栄盖 学雑誌, 45, 107-116 (1987)

6 ) 安田直子, 岡本佳子, 浅野真智子, 深蔵紀子, 尾立純子, 瓦家千代子, 山本悦子, 伊東ソヨ子, 島田豊 治, 難波敦子: 調理済み食品利用の背景一食事作りにか かわる要因一, 栄養学雑誌, 48, 107-119 (1990)

7 ）難波敦子, 尾立純子, 浅野真智子, 瓦家千代子, 島田豊治, 深蔵紀子, 安田直子, 山本悦子: コンビニエ ンス・ストアーの利用の実態と食生活状況, 栄養学雑誌, 59, 135-145 (2001)

8） Schlosser, E. : ファーストフードが世界を食い つくす（2001）草思社

9 ）厚生労働省: 平成 12 年 国民栄盖調查結果

10）厚生省発健医第 115 号：21世紀における国民健 康づくり運動（健康日本21）の推進について (2000.3.31) (受付：平成 14 年 2 月 4 日, 受理：平成 14 年 8 月 27 日) 